\title{
Effect of exposure to adverse climatic conditions on production in Manchega dairy sheep
}

\author{
M. Ramón, ${ }^{* 1}$ C. Díaz,† M. D. Pérez-Guzman, ${ }^{*}$ and M. J. Carabaño† \\ *Centro Regional de Selección y Reproducción Animal (CERSYRA) - Instituto Regional de Investigación y Desarrollo Agroalimentario \\ y Forestal de Castilla-La Mancha (IRIAF-JCCM), 13300 Valdepeñas, Spain \\ †Department of Animal Breeding and Genetics, Instituto Nacional de Investigación y Tecnología Agraria y Alimentaria (INIA), 28040 Madrid, Spain
}

\begin{abstract}
The present study aimed to examine the effects of exposure to adverse weather conditions on milk production to assess the thermotolerance capability of the Manchega breed, a dairy sheep reared in the Mediterranean area, and the extent of decline in production outside the thermal comfort zone. To achieve this purpose, we merged data from the official milk recording of the breed with weather information and used to describe the cold and heat stress response for production traits. Production data consisted of 1,094,804 test-day records from the first 3 lactations of 177,605 ewes gathered between years 2000 to 2010 . For each production trait and climate variable, the thermal load production response was characterized by the estimation of cold and heat stress thresholds that define a thermoneutral zone and the slopes of production decay outside this thermoneutral zone. Overall, we observed a comfort region between 10 and $22^{\circ} \mathrm{C}$ for daily average temperature, 18 and $30^{\circ} \mathrm{C}$ for daily maximum temperature, and from 9 to 18 units for a temperature-humidity index (THI) for all traits. Decline in production due to cold stress effects was of a greater magnitude than heat stress effects, especially for milk yield. Production losses ranged between 7 and 16 and from 0.2 to $0.6 \mathrm{~g} / \mathrm{d}$ per ${ }^{\circ} \mathrm{C}$ (or THI unit) for milk and for fat and protein yields, respectively. For heat stress, the observed decline in production was of 1 to 5 and 0.1 to $0.3 \mathrm{~g} / \mathrm{d}$ per ${ }^{\circ} \mathrm{C}$ (or THI unit) above the threshold for milk yield and for fat and protein yields, respectively. Highly productive animals showed a narrower comfort zone and higher slopes of decay. The study of lagged effects of thermal load showed how consequences of cold and heat stress are already visible in the first hours after exposure. Thus, production losses were due mainly to climate conditions on the day of control and the day before, with conditions on the previous days having a smaller effect. Annual economic
\end{abstract}

Received January 18, 2016.

Accepted March 9, 2016.

${ }^{1}$ Corresponding author: mramon@jccm.es losses due to thermal (cold and heat) stress ranged from 0.1 up to $4 \%$ of total profit depending on which climate variable was considered. Although of small magnitude, the effect of adverse climatic conditions on total annual farm profit is not negligible; thus, we consider the implementation of strategies aimed at reducing these losses to be important. These strategies could be target improving the mitigation strategies as well as obtaining more thermotolerant animals through selection.

Key words: sheep, thermal stress, milk yield, farm profit

\section{INTRODUCTION}

A large proportion of the world's dairy sheep are reared in the Mediterranean area, which is characterized in general by warm to hot, dry summers and mild to cool, wet winters, with specific characteristics depending on the region. In Spain, production is mainly concentrated in the central plateau, characterized by extreme weather conditions, with high summer temperatures and close to freezing temperatures in winters. Predictions relative to climate change effects consider the Mediterranean basin as one of the regions where larger increases in temperatures are expected (e.g., Segnalini et al., 2013). It is widely accepted that exposure to extreme temperatures has negative effects on productive performance (West et al., 2003; Nardone et al., 2010; Sevi and Caroprese, 2012). Moreover, as a consequence of intensification of livestock production systems, animals are now producing at a higher level throughout the year, resulting in more sensitive animals to thermal stress (Kadzere et al., 2002; Bohmanova et al., 2005; Bernabucci et al., 2010); this also results in an increased number of days in which animals are exposed to adverse climatic conditions because of the more intense reproductive rate. This exposure is reflected in a reduction in farm profit either by the decrease of production or by the increase of costs of heat mitigation facilities or both.

Characterization of thermal stress effects on animal production is important to evaluate the economic effect 
on the herd profit, to optimize management of animals under thermal stress, and to design genetic selection strategies. The determination of critical temperatures and effects on productivity have been widely studied in dairy cattle (e.g., Ravagnolo et al., 2000; Hammami et al., 2013; Bernabucci et al., 2014; Carabaño et al., 2014), but little in dairy sheep (Finocchiaro et al., 2005; Peana et al., 2007a,b). However, effects of extreme temperatures vary widely across species and across breeds within species (Silanikove, 2000). Most studies have focused on how heat stress affects milk production, whereas little information on cold stress effects is found in the literature. Curtis (1983) proposed values of 5 and $25^{\circ} \mathrm{C}$ as lower and upper limits for thermal stress for the ovine species; however, those limits may vary for different breeds, productive orientation (meat vs. milk), level of production, and climate. Peana et al. (2007a) found that milk production decreased by $25 \%(0.30$ $\mathrm{kg} / \mathrm{d}$ ) in Sarda sheep when temperatures drop below 0 to $3^{\circ} \mathrm{C}$. For heat stress, Peana et al. (2007b) found that milk production in Sarda decreased by $30 \%(0.39 \mathrm{~kg} / \mathrm{d})$ when maximum and mean temperatures were higher than 21 to $24^{\circ} \mathrm{C}$ and 15 to $21^{\circ} \mathrm{C}$, respectively. Higher thresholds were proposed by Finocchiaro et al. (2005), who found a threshold for the temperature-humidity index (THI) around 73 in a Sicilian dairy breed, similar to the threshold found for dairy cattle, with milk production decreasing by $4.2 \%$ (62.8 g per unit of THI). Likewise, Sevi et al. (2001) indicated that milk production in sheep decreases by $20 \%$ (around $70 \mathrm{~g} / \mathrm{d}$ ) only when temperatures exceed $35^{\circ} \mathrm{C}$ in the Comisana breed.

Another important issue relative to characterization of thermal effects on animal production ability is the existence of a delayed effect of temperature on milk production found in several studies in cattle (West et al., 2003; Bernabucci et al., 2014). For sheep, Finocchiaro et al. (2005) found that weather conditions in a 3 -d period before the milk recording day yielded slightly larger estimated losses than measures on the test day or in any one of the previous $4 \mathrm{~d}$. No other studies dealing with characterization of lag effects in dairy sheep have been found in the literature.

Overall, heat stress in dairy sheep has received limited attention in the literature, and most of the studies have been carried out under experimental conditions and a small number of animals (Sevi et al., 2001; Peana et al., 2007a,b) or with records from commercial farms but with a relatively small data set $(4,000$ ewes in Finocchiaro et al., 2005). The present study aimed to address how adverse climate conditions affect production performance in dairy sheep, with 3 main objectives: (1) the identification of temperature thresholds and lagged effects that define the thermal comfort zone; (2) the quantification of the decay in production due to ther- mal stress; and (3) the estimation of the effect that this decay has on farm profit. This study was conducted with Manchega dairy sheep. Manchega ewes perform under a semi-intensive management system, with lambings distributed along the whole year. These characteristics make this breed a good model to investigate the effects of thermal load on production.

\section{MATERIALS AND METHODS}

\section{Data}

Production Data. Monthly records of milk, fat, and protein yields on the day of control from the official milk recording program of the Manchega dairy sheep breed were provided by AGRAMA (Breed Association of Manchega Sheep, Castile-La Mancha, Spain). Data used were from the first 3 lactations of 191,777 ewes in 175 herds for lambings between 2000 and 2010. Overall, a total of 1,176,670 productive test-day records were used in the present study. In addition, a subset of data comprising those ewes with a production level in the top 20\% (Top20) was analyzed separately to examine if a relationship existed between milk production level and thermotolerance in this population. Top20 was established based on the EBV for milk yield obtained in the routine genetic evaluation of the breed. This Top20 subset consisted of 278,417 records of production data from 39,963 ewes.

Climatic Data. Weather data were provided by the meteorological state agency (AEMET, 2011) and the Irrigation Advisory Service for Farmers (SIAR, Toledo, Spain) in Castile-La Mancha. These data consisted of hourly or daily records of temperature and relative humidity from 60 weather stations distributed in Castile-La Mancha for the years 2000 to 2010. These records were used to calculate the daily average $\left(\mathbf{T}_{\text {avg; }}\right.$; $\left.{ }^{\circ} \mathrm{C}\right)$, maximum $\left(\mathbf{T}_{\max } ;{ }^{\circ} \mathrm{C}\right)$, and minimum $\left(\mathbf{T}_{\min } ;{ }^{\circ} \mathrm{C}\right)$ temperatures, and the daily average $\left(\mathbf{H R}_{\text {avg }} ; \%\right)$, maximum $\left(\mathbf{H R}_{\text {max }} ; \%\right)$, and minimum $\left(\mathbf{H R}_{\text {min }} ; \%\right)$ relative humidity. Two THI, the daily average $\left(\mathbf{T H I} \mathbf{I}_{\mathrm{avg}}\right)$ and the daily maximum ( $\mathbf{T H I} \mathbf{I}_{\max }$ ), were calculated using the formulas presented in Finocchiaro et al. (2005):

$$
\begin{gathered}
\mathrm{THI}_{\mathrm{avg}}=\mathrm{T}_{\mathrm{avg}}-\left(0.55 \times \frac{1-\mathrm{HR}_{\mathrm{avg}}}{100}\right) \times\left(\mathrm{T}_{\mathrm{avg}}-14.4\right), \text { and } \\
\mathrm{THI}_{\max }=\mathrm{T}_{\max }-\left(0.55 \times \frac{1-\mathrm{HR}_{\min }}{100}\right) \times\left(\mathrm{T}_{\max }-14.4\right) .
\end{gathered}
$$

To compute the maximum daily value of the THI index, $\mathrm{THI}_{\max }, \mathrm{HR}_{\max }$, and $\mathrm{HR}_{\min }$ were chosen because daily highest temperatures in the Mediterranean area 
are normally observed at the time of the day when relative humidity is lowest. This type of index showed the best fit to the data in the study by Ravagnolo et al. (2000) in dairy cattle.

Productive data were merged with weather records for the test days included in the study. Weather data from the closest weather station were assigned to each test-day record. The average $( \pm \mathrm{SD})$ distance from farms to the associated weather station was $12.2( \pm 9.3$ $\mathrm{km})$, ranging from 0 to $36.6 \mathrm{~km}$.

For the analyses conducted in the present study, the temperature for the day of milk recording and the $7 \mathrm{~d}$ prior to this day were considered. Records belonging to days with an average daily temperature below 0 and above $30^{\circ} \mathrm{C}$ were discarded because the small number of observations found for those extreme temperatures could provide anomalous estimates. After data editing, the resulting data set consisted of 1,094,804 daily records of production, temperature, and THI belonging to 177,605 ewes. For the Top20, the resulting data set after editing process consisted of 247,362 records from 36,535 ewes.

\section{Assessment of Thermotolerance Thresholds}

Thermal thresholds that determine the comfort region for each production trait (test-day milk, fat, and protein yields), thermal load variable $\left(\mathrm{T}_{\text {avg }}, \mathrm{T}_{\max }, \mathrm{T}_{\min }\right.$, $\mathrm{THI}_{\text {avg }}$, and $\left.\mathrm{THI}_{\max }\right)$ and lag value $(0$ to $7 \mathrm{~d})$, for all animals and for the Top20 data set $(3 \times 5 \times 8 \times 2$ $=240$ cases) were obtained in 2 steps. In a first step, least square solutions for the thermal load effect were obtained under the following model:

$$
\begin{gathered}
y_{i j k l m n o p}=h y_{j}+\text { padim }_{k}+l s_{l}+m s_{m}+T_{n o} \\
+e w e_{p}+e_{i j k l m n o p},
\end{gathered}
$$

where $y_{i j k l m n o p}$ is the ith observation of test-day milk, fat, or protein yields of ewe $p ; h y_{j}$ is the herd-year of lambing (1,173 levels); padim $_{k}$ is the parity-age at parity-DIM (360 levels); $l s_{l}$ is the number of lambs born (3 levels:1, 2, $\geq 3$ ); $m s_{m}$ is the milking shift (3 levels: morning or evening milkings, or unknown); $T_{n o}$ is the climatic variable measuring thermal load in the oth day previous to recording $(o=0, \ldots, 7)$; ewe $e_{p}$ is the ewe producing the data $(177,605$ and 36,535 levels in the overall and Top20 data sets, respectively), fitted as a random effect $\left[N\left(0, \sigma_{\text {ewe }}^{2}\right)\right]$; and $e_{i j k l m n o p}$ is the random error $\left[N\left(0, \sigma_{e}^{2}\right)\right]$. The climatic variable $T_{n o}$ was treated as a fixed factor with each degree of temperature or point in the THI scale representing a level of the factor.
The mean square error (MSE) was computed for each of the cases as

$$
M S E=\sum_{p=1}^{n_{e}} \sum_{i=1}^{n_{p}}\left(y_{i j k l m n o p}-\hat{y}_{i j k l m n o p}\right) / N,
$$

where $\hat{y}_{i j k l m n o p}$ is the predicted ewe test-day record from the solutions of model [1], $n_{p}$ is the number of test-day records per ewe, $n_{e}$ is the number of ewes, and $N$ is the total number of records.

In a second step, the least square means for $T_{n o}$ obtained from each run of model [1] were used to estimate the thermal thresholds by the approach proposed by Muggeo (Muggeo, 2003) and implemented in the Segmented package of R (Muggeo, 2008; https://cran.rproject.org/web/packages/segmented/index.html). As pointed out in the reference manual, package Segmented aims to estimate linear and generalized linear models (and virtually any regression model) having one or more segmented relationships in the linear predictor. In this approach, a prior number of thresholds or break points (where a change in slope occurs) and initial values have to be provided. Break-point estimates and slopes for the regions defined by these estimates are obtained at each cycle in an iterative process until convergence. We provided 2 initial thresholds as a way to examine the effect of heat as well as cold loads on production. These proposed initial thresholds were 10 and $20^{\circ} \mathrm{C}$ for $\mathrm{T}_{\text {avg }}, 20$ and $30^{\circ} \mathrm{C}$ for $\mathrm{T}_{\max }, 0$ and $10^{\circ} \mathrm{C}$ for $\mathrm{T}_{\min }$, and 10 and 20 for both $\mathrm{THI}_{\mathrm{avg}}$ and $\mathrm{THI}_{\max }$. Other initial values were proved, ranging from 0 to $35^{\circ} \mathrm{C}$ depending on the climate variable considered. In a few cases, more than 2 initial points were used for the identification of temperature thresholds.

\section{Estimation of the Thermal Load Effect on Production}

To disentangle the interaction between lagged and thermal load effects on production traits, we performed a joint analysis of the response of a trait to a certain predictor of thermal load and the lagged effects by using a distributed lag nonlinear model for time series data. This is a modeling framework originally conceived to investigate the effect of temperature on health by Armstrong (2006), and further described in Gasparrini and Armstrong (2013) and Gasparrini (2014). This model allows us to describe (non)linear effects of predictors (thermal load in our case) on an outcome (milk, fat, or protein yields in our case) accounting for delayed effects. The methodology is based on the definition of a bidimensional space of functions that simultaneously describe the shape of the relationship along both the space of the predictor and the lag dimension of its 
occurrence. The R package dlnm (Gasparrini, 2011; https://cran.r-project.org/web/packages/dlnm/index. html) was used to perform the analyses.

In the present study, the exposure-response curve (climatic variable-production) was defined either by a polynomial of degree 2 or by a broken line with breaking points defined by the estimated values obtained with the segmented package of $\mathrm{R}$, whereas the lag-response curve was assumed to follow a third-degree polynomial. The lag used ranged from the day of testing to $d 7$ previous to test-day recording, as in the previous analyses. The model provides a grid of predictions of the response variable for each lag ( 0 to 7 ) and suitable values of the predictor (values of each climatic variable) and, therefore, gives an overall picture of the association varying along the 2 dimensions, exposure response and lag response. Supplemental Table S1 (http://dx.doi. org/10.3168/jds.2016-10909) shows goodness of fit for the mixed model analyses.

\section{Estimated Losses Derived from Thermal Stress}

The effect of adverse weather conditions on farm income was estimated for each of the 5 climatic variables, $\mathrm{T}_{\text {avg }}, \mathrm{T}_{\max }, \mathrm{T}_{\min }, \mathrm{THI}_{\text {avg }}$, and $\mathrm{THI}_{\max }$. Productive losses on a given day occurred when the thermal stress threshold (either cold or heat thresholds) was surpassed. Thus, the production loss $\left(P \operatorname{Loss}_{d s t}\right)$ in a given date of the period under study, $d$, and each weather station, $s$, for trait $t$ (milk, fat, or protein yield), was obtained as

$$
P \text { Loss }_{d s t}=\left\{\begin{array}{l}
\left|T_{d s}-T_{o t}\right| \times b_{T t}, \text { if } T_{d s}<T_{c t} \text { or } T_{d s}>T_{h t} \\
0, \text { otherwise }
\end{array}\right\},
$$

where $T_{d s}$ is the value of the climatic variable in date $d$ measured in weather station $s, T_{o t}$ is either the cold $\left(T_{c t}\right)$ or heat $\left(T_{h t}\right)$ threshold corresponding to that climatic variable, and $b_{T t}$ is the slope of the response curve at $T_{d s}$ for trait $t$. The threshold values obtained in the segmented analyses for each climatic variable were used. Slopes $b_{T t}$ were obtained from derivatives of the quadratic functions obtained from the distributed lag nonlinear model analyses at each required value of the climatic variables.

The monetary loss from reduced milk sales $\left(\right.$ SaleLoss $\left._{d s}\right)$ associated with each climatic variable, date, and weather station was then obtained by multiplying the milk reference price for each date by the production loss estimated by [2] for the same date. A detailed description of the payment system of the Manchega sheep milk market is given in Ramón et al. (2010). The payment criterion is based on the fat plus protein content and, therefore, the monetary loss associated with thermal stress in a given date $d$ was obtained as

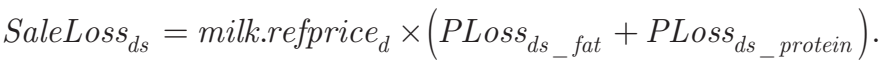

Milk reference prices for each date ( milk.refprice $_{d}$ ) were obtained from the Lonja de Albacete (Albacete, Spain), the official market for the breed. Average milk price for the last 2 yr was $€ 9.20$ /hectograde of fat plus protein content (this price equates to $€ 1.20 / \mathrm{kg}$ of milk with a content equal to the average defined for this breed, $7.18 \%$ of fat, and $5.82 \%$ of protein contents according to data provided by the breeder's association, AGRAMA). For the quantification of sale losses, we considered milk price trends along the year for all the years included in this study.

Total annual monetary losses were calculated and expressed as euros per year and as percentage of decline from total profit per ewe. For the latter, annual average production per ewe (for year y) was set at $220 \mathrm{~kg} / \mathrm{yr}$ :

$$
\begin{gathered}
\text { Total_SaleLoss }(€ / \mathrm{yr})=\sum_{d a y=1}^{365} \text { SaleLoss }_{d s}, \\
\text { Total_SaleLoss }_{y s}(\%)=\frac{\text { Total_SaleLoss }_{y s}(€ / \mathrm{yr})}{220(\mathrm{~kg} / \mathrm{yr}) \times \text { milk.refprice }_{d}(/ \mathrm{kg})} \times 100 .
\end{gathered}
$$

From these formulas, values for productive losses associated with thermal stress were obtained for each weather station location and for all years for which meteorological data were recorded in the stations. This provided a range of values that informed about the fluctuation of losses across the region and across years.

\section{RESULTS AND DISCUSSION}

\section{Characterization of Climatic Conditions}

Figure 1 shows annual temperature trends in CastileLa Mancha for the climatic variables in the period of study. In general, the average temperature evolves gradually throughout the year, without abrupt changes (except for days with storms), with minimum values close to $0^{\circ} \mathrm{C}$ in December and maximum values above $30^{\circ} \mathrm{C}$ in July and part of August. Although average temperature evolves gradually, the thermal width (difference between maximum and minimum temperature) is larger in summer, with values around $20^{\circ} \mathrm{C}$ for the hottest months. Minimum daily temperature remains close to 0 for a long period (from December to midMarch), increases during the spring (decreases in autumn) and reaches its maximum value in summer, with a value around $15^{\circ} \mathrm{C}$. On the other hand, maximum 
Table 1. Mean \pm SD of climatic variables for cold, mild, and hot seasons (defined in Figure 1)

\begin{tabular}{|c|c|c|c|c|c|c|}
\hline \multirow{2}{*}{$\begin{array}{l}\text { Climate } \\
\text { variable }^{1}\end{array}$} & \multicolumn{2}{|c|}{ Cold season $\left(\mathrm{T}<10^{\circ} \mathrm{C}\right)$} & \multicolumn{2}{|c|}{ Mild season $\left(10 \leq \mathrm{T} \leq 20^{\circ} \mathrm{C}\right)$} & \multicolumn{2}{|c|}{ Hot season $\left(\mathrm{T}>20^{\circ} \mathrm{C}\right)$} \\
\hline & Mean \pm SD & Range & Mean \pm SD & Range & Mean \pm SD & Range \\
\hline $\mathrm{T}_{\text {avg }}\left({ }^{\circ} \mathrm{C}\right)$ & $6.4 \pm 2.3$ & {$[-0.0,9.9]$} & $15.6 \pm 2.9$ & {$[10.0,20.0]$} & $24.1 \pm 2.3$ & {$[20.1,30.0]$} \\
\hline $\mathrm{T}_{\max }\left({ }^{\circ} \mathrm{C}\right)$ & $12.3 \pm 3.1$ & {$[5.6,23.0]$} & $21.3 \pm 4.0$ & {$[11.4,24.1]$} & $32.2 \pm 2.8$ & {$[22.8,38.0]$} \\
\hline $\mathrm{T}_{\min }\left({ }^{\circ} \mathrm{C}\right)$ & $0.9 \pm 3.2$ & {$[-11.1,8.7]$} & $7.8 \pm 3.4$ & {$[-2.6,17.9]$} & $15.5 \pm 2.8$ & {$[0.0,23.6]$} \\
\hline $\mathrm{HR}_{\mathrm{avg}}(\%)$ & $74.4 \pm 6.7$ & {$[60.8,85.4]$} & $64.5 \pm 6.3$ & {$[53.5,77.0]$} & $46.5 \pm 4.5$ & {$[39.3,58.2]$} \\
\hline $\mathrm{HR}_{\max }(\%)$ & $90.8 \pm 2.5$ & {$[84.7,94.7]$} & $86.9 \pm 3.3$ & {$[80.2,93.2]$} & $74.3 \pm 4.3$ & {$[66.5,84.4]$} \\
\hline $\mathrm{HR}_{\text {min }}(\%)$ & $51.1 \pm 9.1$ & {$[32.1,67.6]$} & $38.6 \pm 6.9$ & {$[27.8,54.4]$} & $23.1 \pm 3.7$ & {$[17.3,34.3]$} \\
\hline $\mathrm{THI}_{\mathrm{avg}}$ & $7.5 \pm 2.1$ & {$[0.5,12.4]$} & $14.4 \pm 2.3$ & {$[10.2,19.6]$} & $21.0 \pm 1.4$ & {$[17.6,25.0]$} \\
\hline $\mathrm{THI}_{\max }$ & $12.7 \pm 2.4$ & {$[6.2,19.0]$} & $18.7 \pm 2.4$ & {$[11.5,25.0]$} & $24.5 \pm 1.4$ & {$[20.7,29.2]$} \\
\hline
\end{tabular}

${ }^{1} \mathrm{~T}_{\text {avg } / \max / \min }=$ daily average, maximum, and minimum temperature, respectively; $H R_{\text {avg } / \max / \min }=$ daily average, maximum, and minimum relative humidity, respectively; $\mathrm{THI}_{\mathrm{avg}}=$ temperature-humidity index calculated from daily average temperature and relative humidity; $\mathrm{THI}_{\max }=$ temperature-humidity index calculated from daily maximum temperature and minimum relative humidity.

daily temperature increases significantly from around $10^{\circ} \mathrm{C}$ in winter to a maximum value around $35^{\circ} \mathrm{C}$ in the hot months. In addition to cool and hot months, Castile-La Mancha is characterized by a low relative humidity, especially in the hot months (Table 1). The trends observed for $\mathrm{THI}_{\text {avg }}$ and $\mathrm{THI}_{\max }$ closely followed those observed for $T_{\text {avg }}$ and $T_{\max }$ except for the summer months, where the THI variables deviate downwards from the corresponding temperature measures. The THI index used in our study, proposed by Kelly and Bond (1971) and used in Finocchiaro et al. (2005), measures the thermal perception in a way that for a relative humidity of $100 \%$ the values of temperature and THI are equal and as relative humidity decreases so does the thermal perception. Thus, as in our case, the relative humidity is lowest in the hottest months and the thermal perception decreases. Therefore, THI values and their variability in this period of the year are also lower compared with the corresponding temperatures. Depending on the climatic conditions of the region under study, the THI defined in this way could have a limited use. Although these indices and other described in the literature (Bohmanova et al., 2007; Marai et al., 2007) have been widely used, we believe that a more detailed study is necessary on how thermal perception of animals as a function of the temperature, relative humidity, and other climate variables (e.g., the wind speed and direction, altitude, and so on) vary depending on the type of climate. In tropical climates, an increase of temperature is usually associated with an

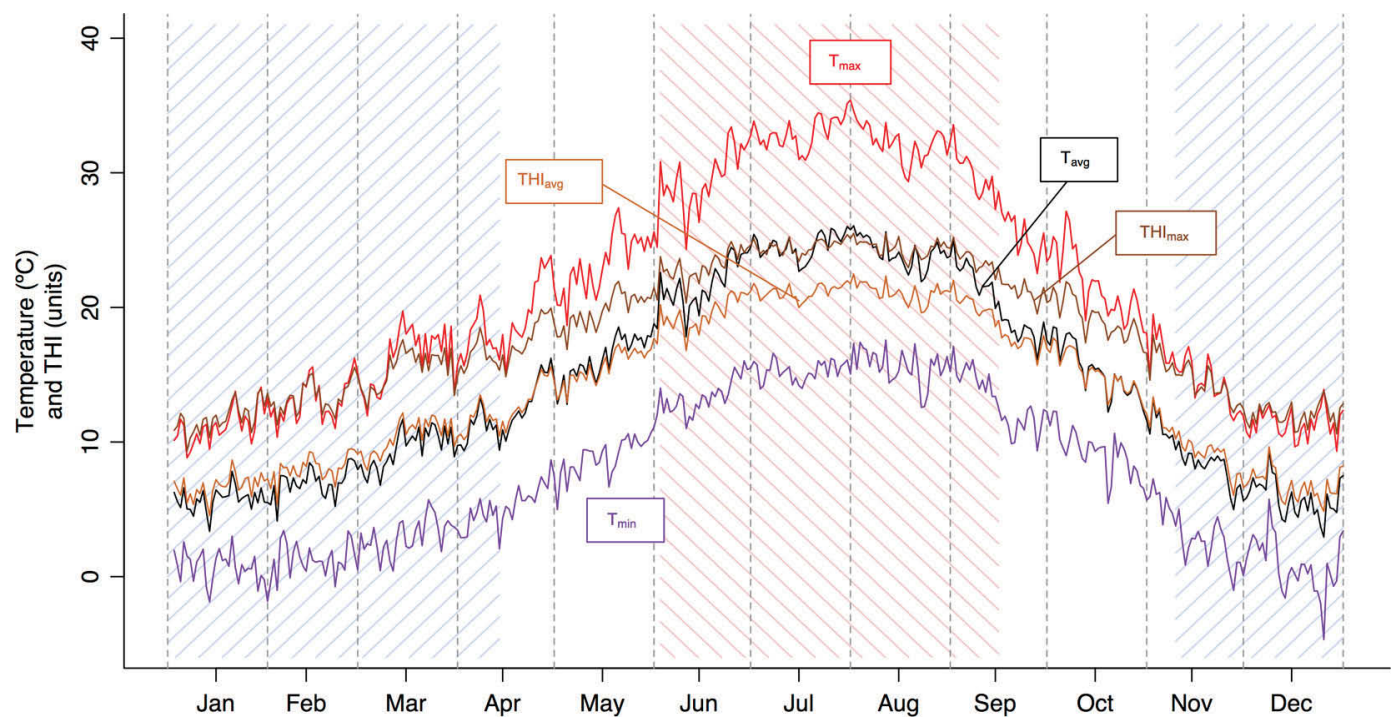

Figure 1. Average values of daily average $\left(\mathrm{T}_{\text {avg }}\right)$, maximum $\left(\mathrm{T}_{\max }\right)$, and minimum $\left(\mathrm{T}_{\min }\right)$ temperatures, and average $\left(\mathrm{THI}_{\text {avg }}\right)$ and maximum $\left(\mathrm{THI}_{\max }\right.$ ) temperature-humidity indexes through the year for years 2000 to 2010 in the weather stations associated with the production records. Shadowed regions represent hot (top-left to bottom-right diagonal lines) and cold (bottom-left to top-right diagonal lines) seasons. Color version available online. 
Table 2. Mean \pm SD for production traits in cold, mild, and hot seasons (defined in Figure 1) in the whole data set and in the data subset including the $20 \%$ most productive animals (Top20)

\begin{tabular}{|c|c|c|c|c|c|c|}
\hline \multirow[b]{2}{*}{ Trait } & \multicolumn{2}{|c|}{ Cold season $\left(\mathrm{T}<10^{\circ} \mathrm{C}\right)$} & \multicolumn{2}{|c|}{ Mild season $\left(10 \leq \mathrm{T} \leq 20^{\circ} \mathrm{C}\right)$} & \multicolumn{2}{|c|}{ Hot season $\left(\mathrm{T}>20^{\circ} \mathrm{C}\right)$} \\
\hline & Total & Top20 & Total & Top20 & Total & Top20 \\
\hline Fat $(\mathrm{g} / \mathrm{d})$ & $77.2 \pm 36.7$ & $93.7 \pm 38.2$ & $77.1 \pm 36.2$ & $93.4 \pm 37.8$ & $72.9 \pm 35.1$ & $88.1 \pm 37.2$ \\
\hline Protein $(g / d)$ & $63.8 \pm 29.1$ & $76.5 \pm 30.0$ & $63.6 \pm 28.5$ & $76.1 \pm 29.4$ & $60.5 \pm 27.9$ & $72.8 \pm 29.0$ \\
\hline
\end{tabular}

increase of the relative humidity, whereas in Mediterranean or continental climates high temperatures are normally associated with low relative humidity.

Based on the trends presented in Figure 1, we defined 3 seasons: a cold season, including the days with an average daily temperature $\left(\mathrm{T}_{\text {avg }}\right)$ below $10^{\circ} \mathrm{C}$; a mild season for days with a $\mathrm{T}_{\text {avg }}$ between 10 and $20^{\circ} \mathrm{C}$; and a hot season, which included the days with a $T_{\text {avg }}$ over $20^{\circ} \mathrm{C}$. Table 1 presents a summary of annual climatic data for each of these 3 seasons.

Table 2 presents general descriptive statistics for milk, fat, and protein yields in the Manchega breed. Following the scheme drawn in Figure 1, production data have been presented for each one of the seasons defined above. For milk yield, production was highest for test-day records from mild season, being lowest for cold months. For fat and protein yields, values recorded during the cold and mild season were similar and lowest for the hot season. The same trend was observed for the Top20 animals.

\section{Assessment of Thermotolerance Thresholds and Slopes of Decay in Production}

The first part of the present study aimed to characterize the thermal load production response through the estimation of the thresholds that define the thermal comfort zone and the slopes of decay in production beyond these thresholds for each trait and climate variable. For this purpose, the least square means for each climate variable obtained from mixed models were used in a piecewise-linear regression procedure to characterize the thermal thresholds and the slopes of production decay. A drawback of the piecewise-linear regression method is that threshold estimation can be strongly dependent on the starting point (Muggeo, 2003). For our study, starting points at 10 and $20^{\circ} \mathrm{C}$ for $\mathrm{T}_{\text {avg }}, 20$ and $30^{\circ} \mathrm{C}$ for $\mathrm{T}_{\max }, 0$ and $10^{\circ} \mathrm{C}$ for $\mathrm{T}_{\min }$, and 10 and 20 for both $\mathrm{THI}_{\text {avg }}$ and $\mathrm{THI}_{\max }$ were initially used, but we confirmed that threshold estimates were substantially independent of the starting point by using another set of initial values.

Figure 2 shows a graphical representation of the relationships between productive traits and thermal load for the complete data set. Relationships between productive traits and thermal load for the Top20 data set were quite similar (Supplemental Figure S1; http:// dx.doi.org/10.3168/jds.2016-10909). Results from mixed model analyses showed a clear inverted U-shaped relationship for fat and protein yields, with production increasing from low values of thermal load to an optimal at the midpoint of the climate variable scale to fall again as thermal load increases. By contrast, milk yield showed the same increase as thermal load raised from low temperatures, whereas little to no effect was observed under heat stress.

Goodness of fit of models [1] assessed by MSE values using alternative measures of thermal load and values of those measures estimated in the test date or in each of the previous $7 \mathrm{~d}$ (lag effect) are shown for all traits in Table 3. In general, models accounting for the thermal load on the test day provided a better fit than using thermal loads from previous days. For measures of the thermal load, models including the average and maximum daily temperature were those that better fit the data for the 3 productive traits, but with small differences from the other models. Correlations between daily maximum temperature in consecutive days were lower than for the daily average temperature measures, the latter showing a steadier trend. Thus, daily maximum temperature could be useful to identify decays in production associated with abrupt changes of temperature, whereas the daily average temperature could be useful to identify production decays associated with cold or hot longer periods. In our study, THI did not capture production decays due to thermal stress in a better way than the temperature variables. As pointed out before, relative humidity in the area under study is steadily low during the hot months, and therefore do not add additional information to that from temperature measures. Again, we consider it necessary to conduct further studies to develop a THI that defines the joint effect of temperature and relative humidity in a better way in our region.

Table 4 shows a summary of the estimated thresholds and slopes of decay due to thermal load for each production trait and climate variable for the test-day and the $7 \mathrm{~d}$ before. For milk yield, the thresholds defining 


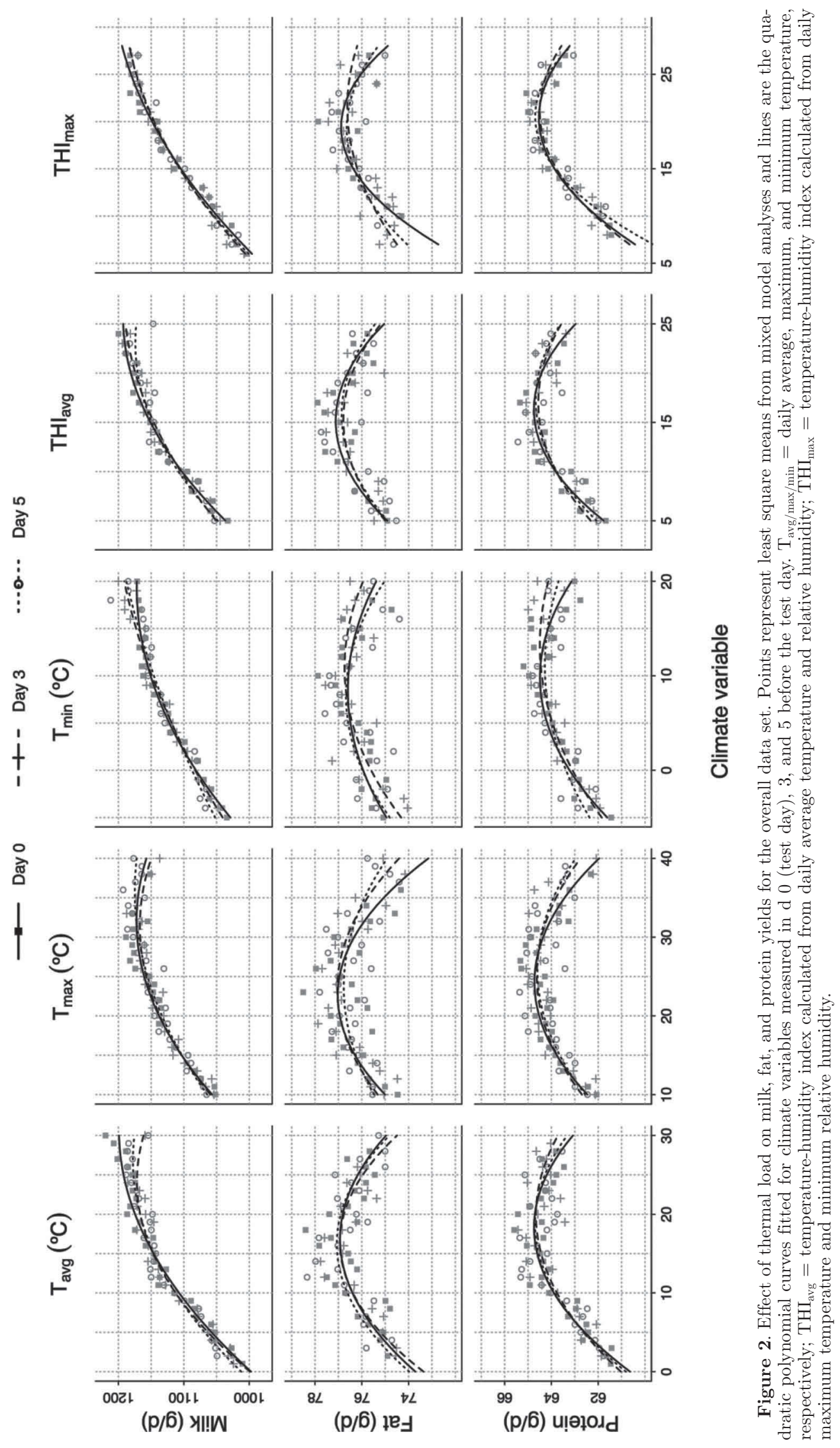


the comfort zone were estimated at $[-1.0,10.2],[11.5$, $21.0]$, and $[19.1,29.6]^{\circ} \mathrm{C}$ for the daily minimum, average, and maximum temperature, respectively, and at $[10.3,18.0]$ and $[13.9,22.0]$ THI units for daily $\mathrm{THI}_{\text {avg }}$ and $\mathrm{THI}_{\max }$, respectively. For fat yield, the thresholds defining the comfort zone were estimated at $[1.3,10.7]$, $[10.2,19.5]$, and $[19.3,30.3]^{\circ} \mathrm{C}$ for the daily minimum, average, and maximum temperature, respectively, and at $[9.8,19.3]$ and $[11.7,20.4]$ THI units for the daily $\mathrm{THI}_{\text {avg }}$ and $\mathrm{THI}_{\max }$, respectively. For protein yield, thresholds were estimated at $[0.3,10.8],[9.8,19.9]$, and $[18.1,30.8]^{\circ} \mathrm{C}$ for the daily minimum, average, and maximum temperature, respectively, and at $[9.6,18.4]$ and $[13.1,20.9]$ THI units for the daily $\mathrm{THI}_{\mathrm{avg}}$ and $\mathrm{THI}_{\max }$, respectively. For the Top20 animals, thresholds were quite similar to those obtained for the complete data, although showed a narrower comfort zone. Table 4 also shows a summary of slopes of production decay outside the comfort region. Slopes for values of the climatic variable below the cold threshold ranged from 7 to $14 \mathrm{~g}$ of milk yield, 0.17 to $0.44 \mathrm{~g}$ of fat yield, and 0.19 to $0.56 \mathrm{~g}$ of protein yield per ${ }^{\circ} \mathrm{C}$ or unit of THI below the threshold. Remember that positive slopes in the cold area are actually associated with losses in production. For values of the climatic values above the hot threshold, slopes of decay were -0.81 to $4.46 \mathrm{~g}$ of milk yield, -0.24 to $-0.12 \mathrm{~g}$ of fat yield, and -0.19 to $-0.07 \mathrm{~g}$ of protein yield per ${ }^{\circ} \mathrm{C}$ or unit of THI above the threshold. When focusing in the Top20 animals, slopes tended to be larger, as expected. In the cool region, slopes were estimated at 10 to $18,0.21$ to 0.53 , and 0.28 to $0.63 \mathrm{~g} /{ }^{\circ} \mathrm{C}$ or THI units for milk, fat, and protein yields, respectively. For the heat region, slopes ranged from 0.65 to $7.25,-0.25$ to -0.17 , and -0.21 to $-0.08 \mathrm{~g} /{ }^{\circ} \mathrm{C}$ or THI units for milk, fat, and protein yields, respectively. For milk yield, estimated slopes for heat stress effect had positive value in most cases, but with large errors of estimation. The thermal load production response curve showed little to no effect of heat stress on milk yield (Figure 2); as a consequence, slopes not significantly different from zero are expected. The smaller amount of data recorded at the high end of values of temperature or THI could also lead to positive estimates when using a polynomial approach, as it occurred in our study. In general, larger slopes were obtained when we addressed the effect of thermal load on production using the THI. However, if we take into account that the scales of both temperatures and THI are different (1 unit of THI approximately comprises $1.25^{\circ} \mathrm{C}$ ) we may conclude that the resulted slopes were similar regardless of the climatic variable used.

The assessment of thermal thresholds and the quantification of production losses derived from exposure to adverse climatic conditions have been addressed before in other breeds and species. Most of those studies focused on how heat stress affects milk production, whereas little information on cold stress effects was found in the literature. A work by Sevi and Caroprese (2012) reviewed the effect of heat stress on milk production, immunity, and udder health in sheep. Heat thresholds from 21 to $24^{\circ} \mathrm{C}$ for daily average temperature (Peana et al., 2007b), over $35^{\circ} \mathrm{C}$ for maximum temperature (Caroprese et al., 2011), or over 23 for THI (Finocchiaro et al., 2005) have been reported. For cold stress, Peana et al. (2007a) described a reduction of milk production when THI drops below 60 to 65 (approximately equal to 14 to 16 in the Celsius degree scale). Differences among thresholds found in these studies may be due to differences among breeds and to the presence or absence of freezing and heating facilities that could contribute to mitigate thermal stress.

\section{Estimation of the Thermal Load Effect on Production Accounting}

An important aspect in the characterization of animal response to thermal stress is the assessment of the lagged effect that weather has on production (West et al., 2003). To disentangle the interaction between lagged and thermal load effects on production traits,

Table 3. Mean squared errors (MSE) of mixed models for all data and for the $20 \%$ most productive animals (Top20); data are ranges for different models carried out, with minimum corresponding to MSE for the models including climate variables on day of test-day, and maximum corresponding to MSE for models including climate variables on d 7 before test-day ${ }^{1}$

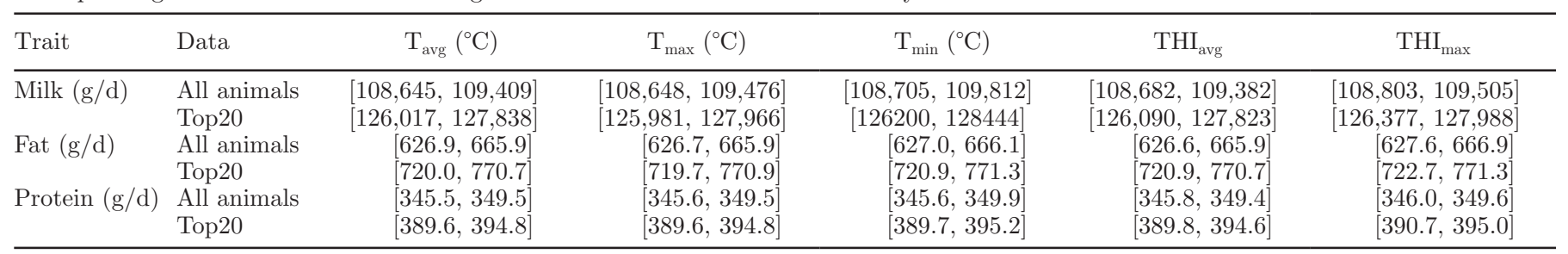

${ }^{1} \mathrm{~T}_{\mathrm{avg} / \max / \min }=$ daily average, maximum, and minimum temperature, respectively; $\mathrm{THI}_{\mathrm{avg}}=$ temperature-humidity index calculated from daily average temperature and relative humidity; $\mathrm{THI}_{\max }=$ temperature-humidity index calculated from daily maximum temperature and minimum relative humidity. 
we performed a joint analysis of the response of a trait to a certain predictor of thermal load and the lagged effects. Previous studies have dealt with the effect of thermal load and the lag effect on productivity in separate ad hoc analyses (e.g., Finochiaro et al., 2005; Bernabucci et al., 2014). Figure 2 showed the effect that weather conditions in the day of control and in the previous days have on animal performance in a similar approach to previous studies. Thus, the response curves corresponding to different lags are drawn without considering the correlation structure behind weather conditions in consecutive days (temperatures or THI

Table 4. Mean \pm SD and range (within brackets) of the estimated thresholds and slopes outside the comfort zone for each production trait and climate variable ${ }^{1}$ for the time interval from $7 \mathrm{~d}$ before control to the day of test-day $($ day $=0)$, in the total data set and in the data subset including the $20 \%$ most productive animals (Top20)

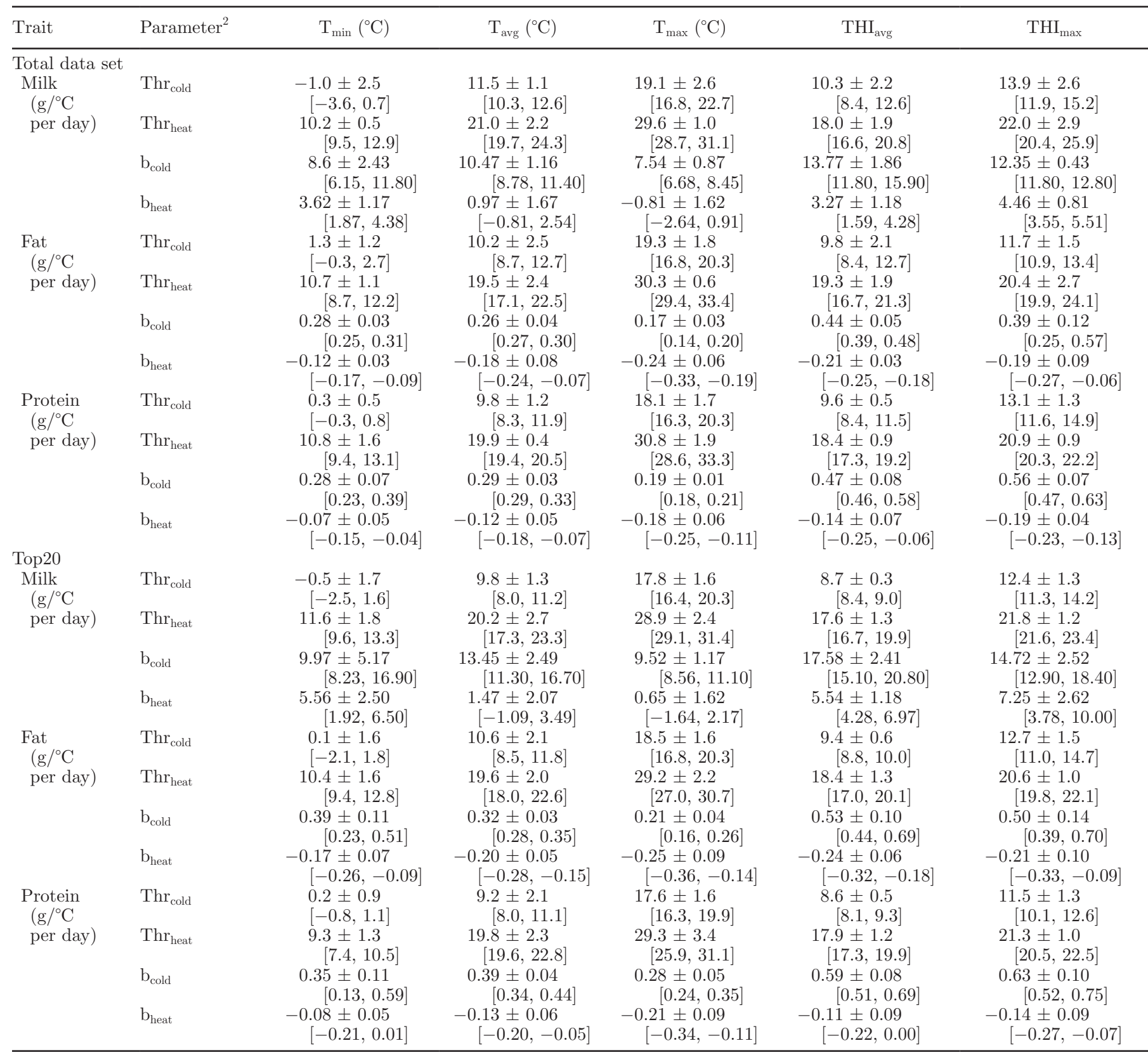

${ }^{1} \mathrm{~T}_{\mathrm{avg} / \max / \min }=$ daily average, maximum, and minimum temperature, respectively; $\mathrm{THI}_{\mathrm{avg}}=$ temperature-humidity index calculated from daily average temperature and relative humidity; $\mathrm{THI}_{\max }=$ temperature-humidity index calculated from daily maximum temperature and minimum relative humidity.

${ }^{2} \mathrm{Thr}_{\text {cold }}=$ cold threshold; $\mathrm{Thr}_{\text {heat }}=$ heat threshold; $\mathrm{b}_{\text {cold }}=$ slope below cold threshold; $\mathrm{b}_{\text {heat }}=$ slope above heat threshold. 
values in consecutive days tend to be highly correlated) and the relationship between lag and weather conditions (lag effects can be more important under some weather conditions that others). The advantage of the joint analysis carried out is that it allows the simultaneous assessment of nonlinear and delayed effects between predictors (in our case, weather variables) and an outcome (production traits in our study). A main output from this analysis is a 3-dimensional plot of the predicted outcome over the grid of predictor lag values. This 3-dimensional plot represents the response surface of predicted values of production for changes in the climatic variable for a given day, and for changes in the climate variable in the days before test day (lag period). Three-dimensional plots resulted from our analysis are provided as supplementary material (Supplemental Figure S2; http://dx.doi.org/10.3168/jds.2016-10909). Two figures obtained from these 3-dimensional plots are presented here. Figure 3 provides the corresponding 2-dimensional plot of the predicted response of production due to thermal load in previous days (d 0,3 , and 5 before the test day). Figure 4 shows the 2-dimensional plot of the predicted response of production resulting from changes in thermal load through a lag period of $5 \mathrm{~d}$ before test-day recording and evaluated at 3 climate scenarios (cold, mild, and hot conditions). These 2 figures represent the relationships obtained from the complete data set. For the Top20 data set, relationships were quite similar and these figures are provided as supplementary material (Supplemental Figures S3 and S4; http://dx.doi.org/10.3168/jds.2016-10909).

As for the results shown in Figure 2, the thermal load production response curves in Figure 3 showed an inverted U-shaped relationship for fat and protein yields. Milk yield showed a production decline only under cold stress and little to no effect was observed for a high thermal load. Again, production losses due to cold stress were higher than those for heat stress. Thus, the observed patterns of response for weather variables obtained in the milk test day were quite similar in Figures 2 and 3. However, response curves for weather variables registered in previous days to the test date differed substantially when the response to thermal load curve was jointly estimated with the lag effects (Figure 3) compared with the response curves obtained in separate analyses (Figure 2). Thermal load production curves for days before the test day were much flatter when the lag and thermal load effects were analyzed jointly (Figure 3) than when response curves to weather conditions were obtained in separate analyses for each lag (Figure 2).

As discussed, Figure 4 allows us to examine the predicted response in production when considering climate trend in the days before the test day (lag period) and under 3 possible scenarios: a first scenario (cold) in which temperatures (and THI) were low; a second scenario (mild) in which climate conditions were optimal and no thermal stress effect was expected; and a third scenario (heat) in which animals were exposed to high temperatures (and THI). The 10th, 50th, and 90th percentiles for each climatic variable defined the 3 scenarios, respectively. For mild conditions, no effect on production was observed for any of the lag values, as expected. For cold and hot conditions, the pattern for lag effects on production differed among traits. For milk volume, under cold conditions, the day showing the largest effect on milk yield was the day of control, with effects for other previous days decreasing as they separate from the test date. For hot weather, nearly no effect or a positive effect was observed for the test day and for previous days. For this trait, a slightly different pattern was also observed for the total and the Top20 data sets (see Supplemental Figure S4; http://dx.doi. org/10.3168/jds.2016-10909), with a decreasing trend for the days previous to negative values for weather variables registered around d 5 prior to the test date. For fat and protein yields, lags 0 and 5 showed the largest effects under hot conditions, whereas under cold weather lag 0 was the lag that always showed the largest effect on components, as also observed for milk volume. Lag effects of high temperatures on milk production have been previously found in sheep and cattle. In dairy sheep, Finocchiaro et al. (2005) found a significant decay in production for THI values above 23 from $3 \mathrm{~d}$ before the test day. For dairy cattle, 2- to 4-d lags have been found in different studies (West et al., 2003; Spiers et al., 2004; Bernabucci et al., 2014), In our study, the weather conditions on the test day and the 2 previous days showed the largest effects for both the cold and heat conditions. However, delayed effects from weather conditions $5 \mathrm{~d}$ before the milk recording were also observed under hot conditions in some cases. A possible explanation of this trend could be related to the way animals respond to heat load and their acclimatization. Although abrupt climate changes can occur leading to important decays in production in very short periods of time, it is expected that these changes occur gradually with moderate and spread decays, whereas the thermal stress situation remains. Acclimation of animals to thermal stress conditions would result, therefore, in a more pronounced decay at the beginning of exposure, followed by a lower decay after acclimation. For that reason, exposure to a 3-d period of high heat load before the test day may result in an effect not significantly different from that derived from the heat load on the day of control. However, if exposure were maintained during a longer (e.g., $5 \mathrm{~d}$ ) period then the reduction in milk production would be greater and due 
RAMÓN ET AL.

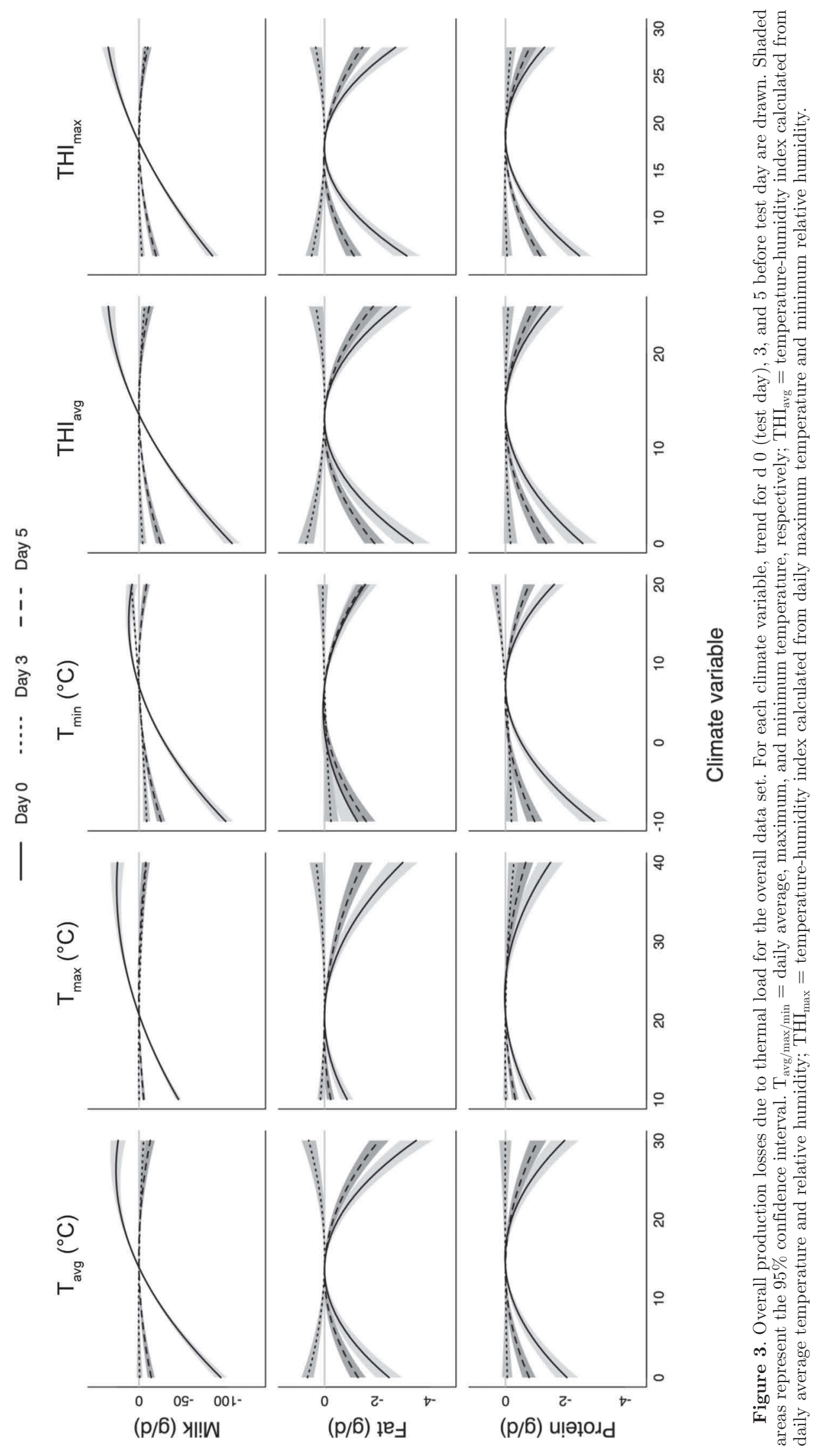


THERMAL STRESS IN MANCHEGA SHEEP
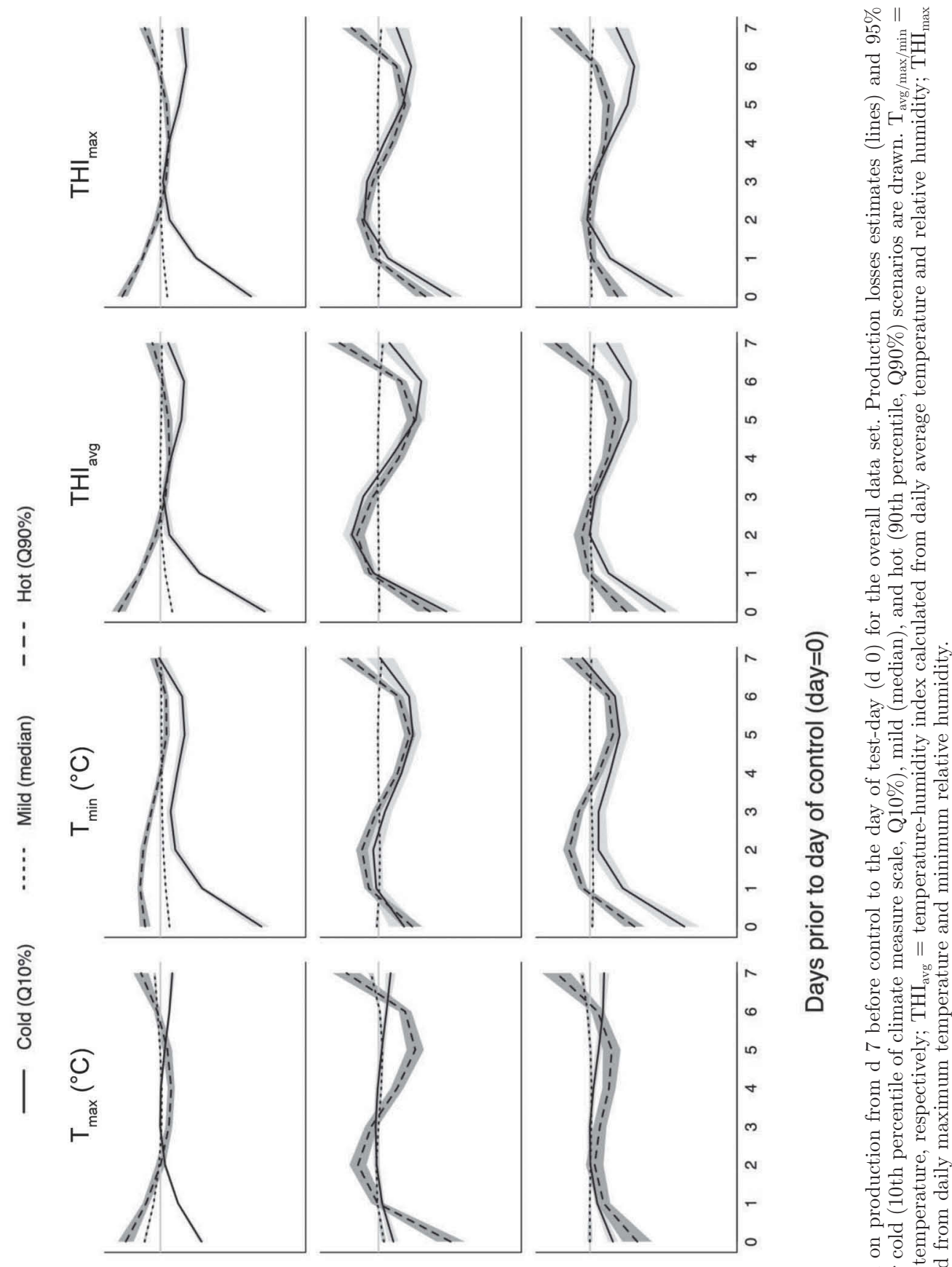

웡

ㄱㅇㅇ

की

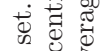

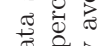

을

需

b일

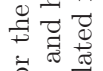

oิ

이류.

음

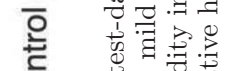

웡

하웜웝

तิ

은

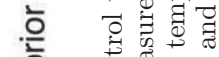

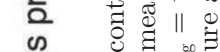

สิ

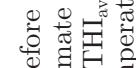

능

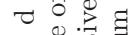

명 苛

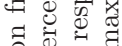

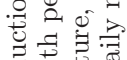

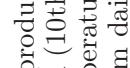

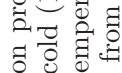
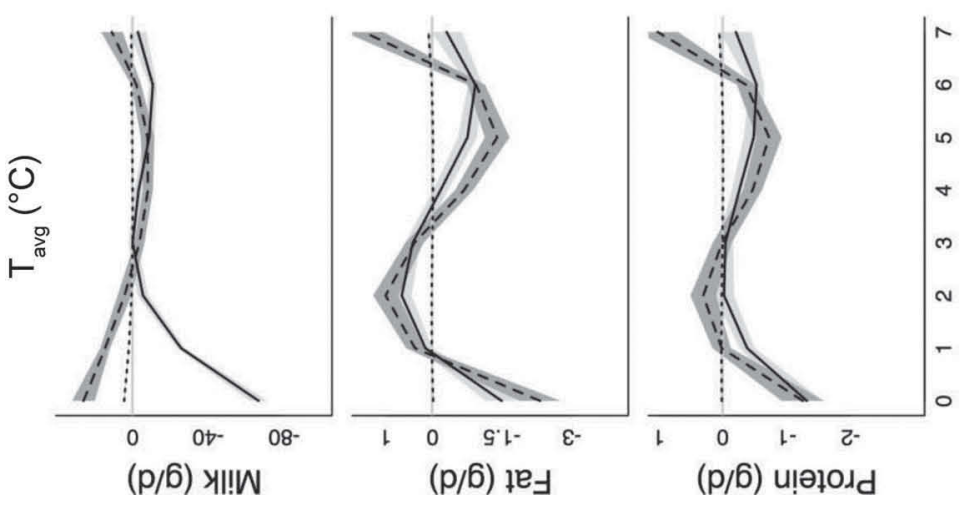

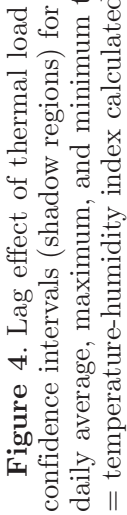


to cumulative effects of weather conditions in previous days.

\section{Estimated Decay in Production and Profit}

Decays in production and its effect on farm profit due to thermal stress are summarized in Table 5 for the overall data and for the Top20 animals, and graphically represented in Figure 5 for the complete data set [and in Supplemental Figure S5 (http://dx.doi.org/10.3168/ jds.2016-10909) for the Top20 data set]. As expected, losses due to heat stress were concentrated in summer and reached its maximum in wk 30 (second half of July). Climate variables $\mathrm{T}_{\max }$ and both THI were the variables that reported higher losses due to heat stress (Figure 5). Losses due to cold stress were higher around the first and last week of the year. In our study, the $\mathrm{T}_{\text {avg }}$ was the climatic variable that reported the greater losses due to cold stress. As discussed, exposure to cold weather resulted in greater losses. Estimated annual decays in production derived from cold stress ranged from 2 to $7 \mathrm{~kg}$ /ewe for milk yield and from 0.03 to 0.2 $\mathrm{kg}$ /ewe for fat and protein yields, depending on the climatic variable. These production losses resulted in estimated annual economic losses of $€ 0.1$ to 6.3/ewe, representing 0.1 to $2.4 \%$ of the total annual benefit. Regarding exposure to hot weather, estimated annual decays in production ranged from 0.09 to 0.2 and 0.08 to $0.1 \mathrm{~kg} /$ ewe for fat and protein yields, respectively. The estimated annual economic losses derived from heat stress effects ranged from $€ 0.2$ to 3.9 /ewe, which represents 0.1 to $1.5 \%$ of the total annual benefit. The effect of thermal stress on farm profit was greater in the highly productive (Top20) animals. For this group, annual production losses due to cold stress ranged between 2 and $10 \mathrm{~kg} /$ ewe for milk and from 0.1 to 0.3 $\mathrm{kg}$ /ewe for fat and protein yields. Expressed in terms of farm profit, estimated annual economic losses were of $€ 0.6$ to 6.8 /ewe, which represents the 0.2 to $2.6 \%$ of the total annual profit. Under heat stress, production in the Top20 animals decreased from 0.1 to $0.2 \mathrm{~kg} /$ ewe for fat and protein yields. The derived economic losses ranged from €0.2 to 6.2/ewe, representing 0.1 to $2.4 \%$ of the total annual profit per ewe.

In dairy sheep, Finocchiaro et al. (2005) reported a yield decrease per unit of THI above 23 of 62.8 and 8.9 $\mathrm{g} /$ ewe for milk and fat plus protein yields, respectively, for the Valle del Belice breed, which represents 4.2 and $4.9 \%$ of the production of the breed. For Sarda ewes, Peana et al. (2007b), under experimental conditions, reported a decay of $15 \%$ in milk yield for maximum ambient temperatures higher than 21 to $24^{\circ} \mathrm{C}$, and of $20 \%$ when THI drops below a THI of 60 to 65 (approximately equal to a THI of 14 to 16 in the Celsius degree scale). In dairy cattle, Bohmanova et al. (2007) reported annual milk yield losses derived from exposure to hot weather ranged from 101 to $127 \mathrm{~kg}$ in Athens (Georgia) and from 124 to $168 \mathrm{~kg}$ in Phoenix (Arizona), which represents 1 to $2 \%$ assuming a total annual production of around $9,000 \mathrm{~kg} / \mathrm{cow}$. In a study conducted in Holsteins under a continental climate in Luxembourg, Hammami et al. (2013) reported maximum production decays due to heat stress of 54, 5.7, and $4.2 \mathrm{~kg} /$ year from milk, fat, and protein, respectively, which represented approximately $0.6,0.9$, and $0.7 \%$ of total annual production for those traits. Comparison of the estimated productive and economic losses between values found in the literature is not strictly possible due to the wide variety of climatic variables used in our study and, more importantly, the great variability of climates that characterize each region and determine the scale in which each climatic variable is measured. Nevertheless, production losses observed in the present study were similar to those reported in dairy cattle and somehow lower than those described for dairy sheep. It is important to mention here that production loss associated with heat stress has been found to be severely underestimated when production is measured monthly, as it happens in the commercial milk recording systems compared with estimates obtained from daily recording of milk production and temperature by Freitas et al. (2006). The inclusion of other sources of information, such as health status of animals, may improve the estimates of thermal stress effects. For this work, no information on SCC in milk was available. It is known that increased levels of SCC lead to important production and economic losses (Legarra et al., 2007; Cuccuru et al., 2011; Martí De Olives et al., 2013), and that heat stress could induce an increase of SCC levels (Carabaño et al., 2014). Considering both production and health traits jointly may help to better characterize what production losses are due to thermal stress and what are due to a deterioration of health status or to other factors. Finally, the definition of new phenotypes related to thermal load could also improve the characterization of animal response to thermal stress. Recent studies have taken advantage of the use of metabolic profiles to evaluate heat stress effects on yield and udder health traits showing the potential of some biomarkers as indicators of heat stress (Hamzaoui et al., 2013; Hammami et al., 2015).

\section{CONCLUSIONS}

The present study aimed to address the effect of adverse climate conditions on production capability of an autochthonous sheep breed reared in south-central Spain. This region is characterized by the presence of 
extreme temperatures during long periods throughout the year. The study of relationships between production traits and climatic variables allowed us to identify a comfort zone, between 11 and $21^{\circ} \mathrm{C}$ of average daily temperature and between 19 and $30^{\circ} \mathrm{C}$ of maximum daily temperature, in which animals could express their highest production ability. For heat stress, both maximum and average temperatures showed the best goodness of fit and captured largest losses in production. Outside this comfort zone, production decreased, this decrease being different depending on which trait and climatic measures were considered. Cold stress effects on production resulted in higher magnitude than heat stress, especially for milk volume. More specifically, for this breed, milk yield production was reduced only when ewes were exposed to low temperatures and no significant negative effects were observed due to exposure to high temperatures. Focusing on milk quality, exposure to high temperatures led to a significant reduction in fat and protein production, quite similar to that caused by cold stress. The study of lagged effect of thermal load showed that conditions on the test day and the $2 \mathrm{~d}$ before mainly determine how animals respond to thermal stress. The productive loss due to heat stress was estimated as 0.1 to $2.6 \%$ of total annual profit per ewe depending on the climatological variable or index used to measure the thermal load and on the production level of the animals. Animals that are more productive showed larger production decays under thermal stress. Although of low magnitude, the effect of adverse climatic conditions on total annual farm profit is not negligible; thus, we consider the implementation of strategies aimed at reducing these losses important. These mechanisms could target improving the mitiga-

Table 5. Decline in production (mean $\pm \mathrm{SD}$ ) and profit (minimum and maximum losses observed at different weather stations, in brackets) due to cold/heat load for each production trait and climate variable ${ }^{1}$

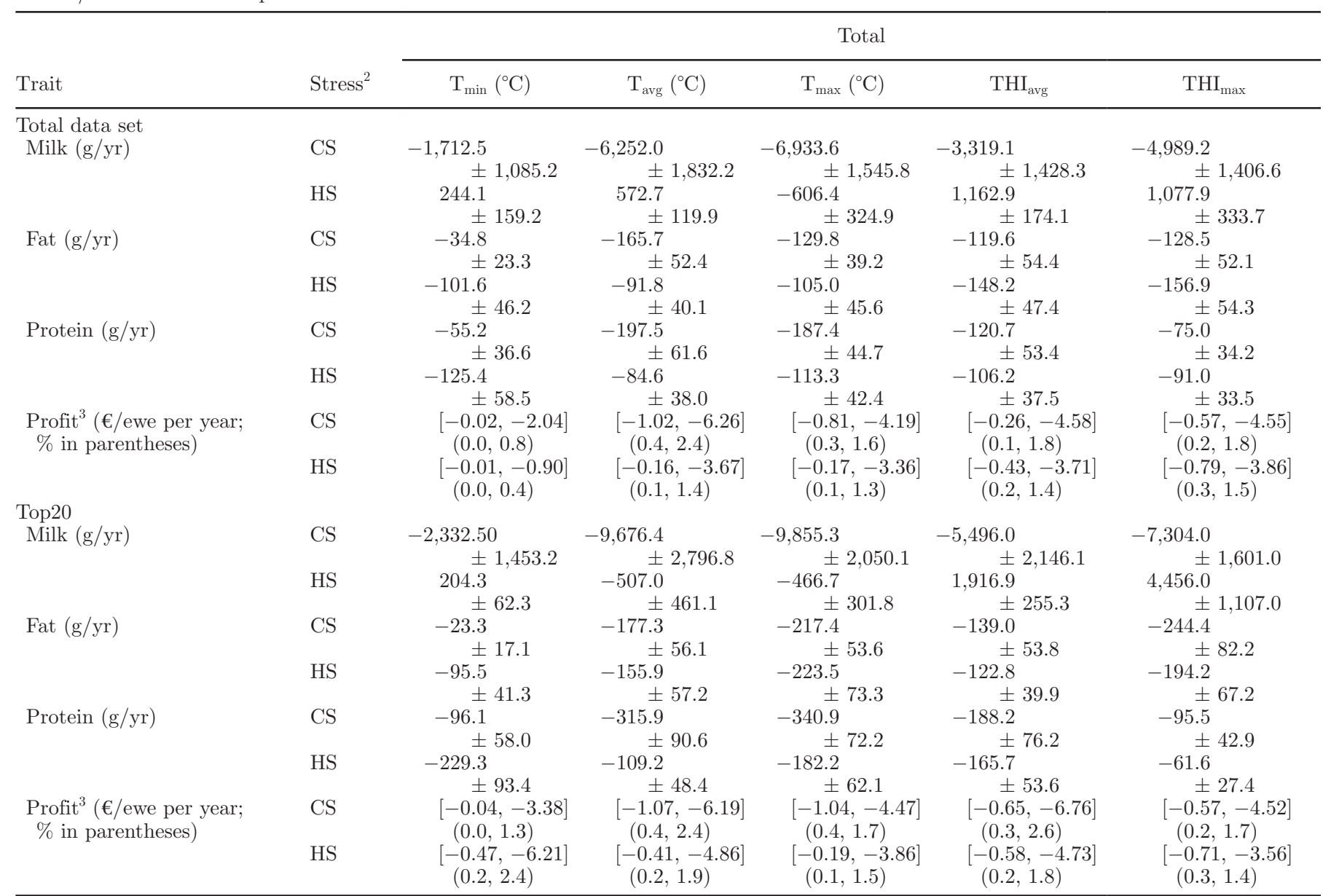

${ }^{1} \mathrm{~T}_{\mathrm{avg} / \max / \min }=$ daily average, maximum, and minimum temperature, respectively; $\mathrm{THI}_{\mathrm{avg}}=$ temperature-humidity index calculated from daily average temperature and relative humidity; $\mathrm{THI}_{\max }=$ temperature-humidity index calculated from daily maximum temperature and minimum relative humidity; Top20 = data subset including the $20 \%$ most productive animals.

${ }^{2} \mathrm{CS}=$ cold stress; HS = heat stress.

${ }^{3}$ Profit was expressed as $€ /$ year per ewe and as percentage from the total profit (within parentheses). 


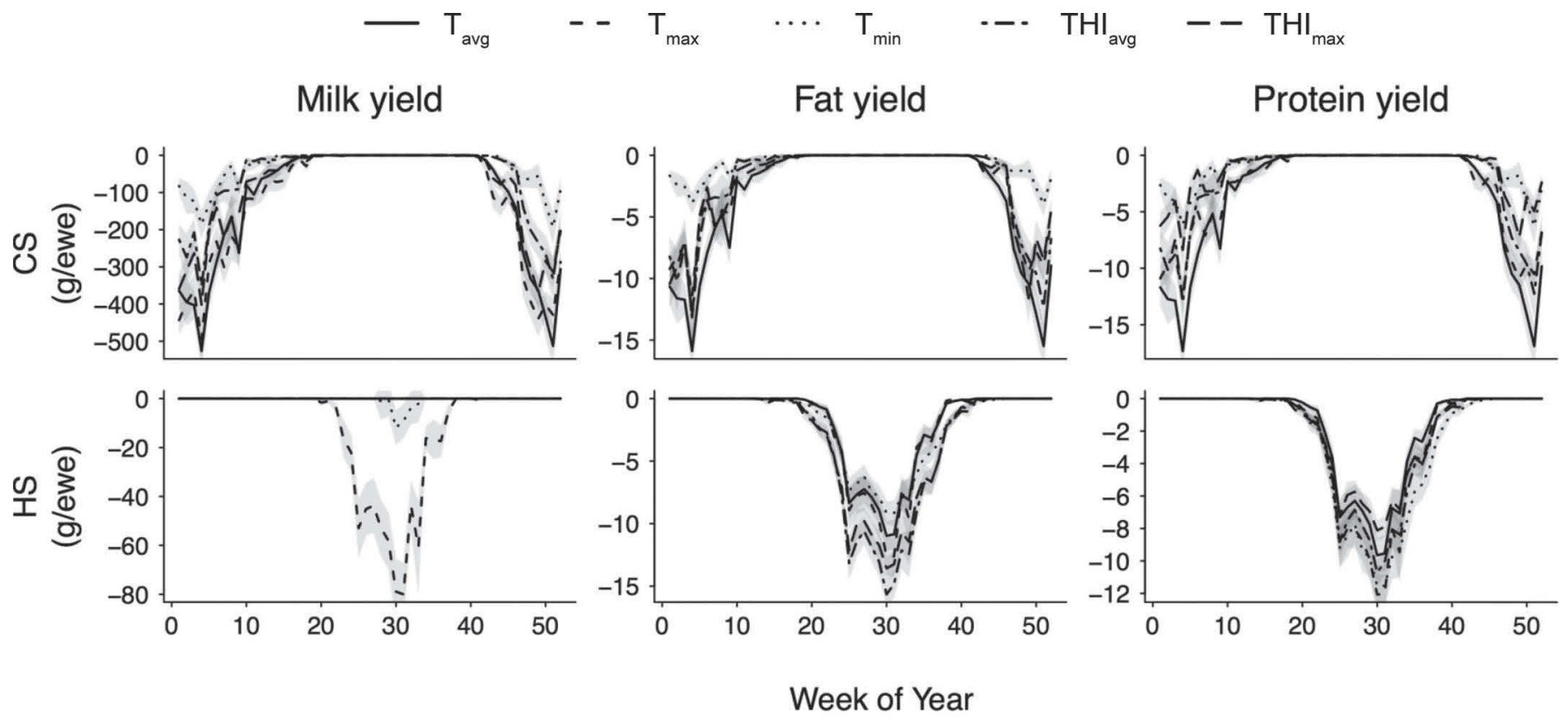

Figure 5. Trends of production losses along the year derived from cold (CS) and heat (HS) stress for the overall data set. Shaded areas represent minimum and maximum losses observed at different weather stations. $\mathrm{T}_{\mathrm{avg} / \mathrm{max} / \min }=$ daily average, maximum, and minimum temperature, respectively; $\mathrm{THI}_{\text {avg }}=$ temperature-humidity index calculated from daily average temperature and relative humidity; $\mathrm{THI}_{\max }=$ temperaturehumidity index calculated from daily maximum temperature and minimum relative humidity.

tion mechanism of animals or obtaining more thermotolerant animals through selection.

\section{ACKNOWLEDGMENTS}

This study was financed by the project INIA-FEDER: RTA2011-00108. The authors thank Agencia Estatal de Meteorología (AEMET), Madrid, Spain, and Servicio Integral de Asesoramiento al Regante (SIAR), Toledo. Spain, for providing the meteorological records, and Asociación Nacional de Criadores de Ganado Ovino Selecto de Raza Manchega (AGRAMA), Albacete, Spain, for providing the production data.

\section{REFERENCES}

AEMET. 2011. Iberian Climate Atlas. Air temperature and precipitation (1971-2000). Agencia Estatal de Meteorología (AEMET). Ministerio de Medio Ambiente y Medio Rural y Marino. Instituto de Meteorología de Portugal. Accessed Dec. 20, 2013. http://www.aemet.es/documentos/es/conocermas/publicaciones/ Atlas-climatologico/Atlas.pdf.

Armstrong, B. 2006. Models for the relationship between ambient temperature and daily mortality. Epidemiology 17:624-631.

Bernabucci, U., S. Biffani, L. Buggiotti, A. Vitali, N. Lacetera, and A. Nardone. 2014. The effects of heat stress in Italian Holstein dairy cattle. J. Dairy Sci. 97:471-486.

Bernabucci, U., N. Lacereta, L. H. Baumgard, R. P. Rhoads, B. Ronchi, and A. Nardone. 2010. Metabolic and hormonal acclimation to heat stress in domesticated ruminants. Animal 4:1167-1183.

Bohmanova, J., I. Misztal, and J. B. Cole. 2007. Temperature-humidity indices as indicators of milk production losses due to heat stress. J. Dairy Sci. 90:1947-1956.
Bohmanova, J., I. Misztal, S. Tsuruta, H. D. Norman, and T. J. Lawlor. 2005. National genetic evaluation of milk yield for heat tolerance of United States Holsteins. Interbull Bull. 33:160-162.

Carabaño, M. J., K. Bachagha, M. Ramón, and C. Díaz. 2014. Modeling heat stress effect on Holstein cows under hot and dry conditions: Selection tools. J. Dairy Sci. 97:7889-7904.

Caroprese, M., M. Albenzio, A. Bruno, V. Fedele, A. Santillo, and A. Sevi. 2011. Effect of solar radiation and flaxseed supplementation on milk production and fatty acid profile of lactating ewes under high ambient temperature. J. Dairy Sci. 94:3856-3867.

Cuccuru, C., M. Meloni, L. Scaccabarozzi, C. Locatelli, P. Moroni, and V. Bronzo. 2011. Effects of intramammary infections on somatic cell score and milk yield in Sarda sheep. N. Z. Vet. J. 59:128-131.

Curtis, S. E. 1983. Environmental Management in Animal Agriculture. Iowa State Press, Ames.

Finocchiaro, R., J. B. C. H. M. van Kaam, B. Portolano, and I. Misztal. 2005. Effect of heat stress on production of Mediterranean dairy sheep. J. Dairy Sci. 88:1855-1864.

Freitas, M. S., I. Misztal, J. Bohmanova, and J. West. 2006. Utility of on- and off-farm weather records for studies in genetics of heat tolerance. Livest. Sci. 105:223-228.

Gasparrini, A. 2011. Distributed lag linear and non-linear models in R: The package dlnm. J. Stat. Softw. 43:1-20.

Gasparrini, A. 2014. Modeling exposure-lag-response associations with distributed lag non-linear models. Stat. Med. 33:881-899.

Gasparrini, A., and B. Armstrong. 2013. Reducing and meta-analyzing estimates from lag non linear models. BMC Med. Res. Methodol. $13: 1$.

Hammami, H., J. Bormann, N. M'hamdi, H. H. Montaldo, and N. Gengler. 2013. Evaluation of heat stress effects on production traits and somatic cell score of Holsteins in a temperate environment. J. Dairy Sci. 96:1844-1855.

Hammami, H., J. Vandebplas, M. L. Vanrobays, B. Rekik, C. Bastin, and N. Gengler. 2015. Genetic analysis of heat stress effects on yield traits, udder health and fatty acids of Wallon Holstein cows. J. Dairy Sci. 98:4956-4968.

Hamzaoui, S., A. A. Salama, E. Albanell, X. Such, and G. Caja. 2013 Physiologycal responses and lactational performances of late- 
lactation dairy goats under heat stress conditions. J. Dairy Sci. 96:6355-6365.

Kadzere, C. T., M. R. Murphy, N. Silanikove, and E. Maltz. 2002. Heat stress in lactating dairy cows: A review. Livest. Prod. Sci. 77:59-91.

Kelly, C. F., and T. E. Bond. 1971. Bioclimatic Factors and Their Measurement. A Guide to Environmental Research on Animals. Nat. Acad. Sci., Washington, DC.

Legarra, A., M. Ramón, E. Ugarte, M. D. Pérez-Guzmán, and J. Arranz. 2007. Economic weights of somatic cell score in dairy sheep. Animal 1:205-212.

Marai, I. F. M., A. A. El-Darawany, A. Fadiel, and M. A. M. Abdel-Hafez. 2007. Physiological traits as affected by heat stress in sheep-A review. Small Rumin. Res. 71:1-12.

Martí De Olives, A., J. R. Díaz, M. P. Molina, and C. Peris. 2013. Quantification of milk yield and composition changes as affected by subclinical mastitis during the current lactation in sheep. J. Dairy Sci. 96:7698-7708.

Muggeo, V. M. R. 2003. Estimating regression models with unknown breakpoint. Stat. Med. 22:3055-3071.

Muggeo, V. M. R. 2008. Segmented: An R package to fit regression models with broken-line relationships. R News 8:20-25.

Nardone, A., B. Ronchi, N. Lacetera, M. S. Ranieri, and U. Bernabucci. 2010. Effects of climate changes on animal production and sustainability of livestock systems. Livest. Sci. 130:57-69.

Peana, I., C. Dimauro, M. Carta, M. Gaspa, G. Fois, and A. Cannas. 2007a. Cold markedly influences milk yield of Sardinian dairy sheep farms. Proc. 17th ASPA Congress, Alghero, May 29-June 1, 2007. (Abstr.)
Peana, I., G. Fois, and A. Cannas. 2007b. Effects of heat stress and diet on milk production and feed and energy intake of Sarda ewes. Ital. J. Anim. Sci. 6:577-579.

Ramón, M., A. Legarra, E. Ugarte, J. J. Garde, and M. D. PérezGuzmán. 2010. Economic weights for major milk constituents of Manchega dairy ewes. J. Dairy Sci. 93:3303-3309.

Ravagnolo, O., I. Misztal, and G. Hoogenboom. 2000. Genetic component of heat stress in dairy cattle, development of heat index function. J. Dairy Sci. 83:2120-2125.

Segnalini, M., U. Bernabucci, A. Vitali, A. Nardone, and N. Lacetera. 2013. Temperature humidity index scenarios in the Mediterranean basin. Int. J. Biometeorol. 57:451-458.

Sevi, A., G. Annicchiarico, M. Albenzio, L. Taibi, A. Muscio, and S. Dell'Aquila. 2001. Effects of solar radiation and feeding time on behavior, immune response and production of lactating ewes under high ambient temperature. J. Dairy Sci. 84:629-640.

Sevi, A., and M. Caroprese. 2012. Impact of heat stress on milk production, immunity and udder health in sheep: A critical review. Small Rumin. Res. 107:1-7.

SIAR. 2015. Servicio Integral de Asesoramiento al Regante de CastillaLa Mancha. Accessed Jan. 31, 2015. http://crea.uclm.es/siar.

Silanikove, N. 2000. Effects of heat stress on the welfare of extensively managed domestic ruminants. Livest. Prod. Sci. 67:1-18.

Spiers, D. E., J. N. Spain, J. D. Sampson, and R. P. Rhoads. 2004. Use of physiological parameters to predict milk yield and feed intake in heat-stressed dairy cows. J. Therm. Biol. 29:759-764.

West, J. W., B. G. Mullinix, and J. K. Bernard. 2003. Effects of hot, humid weather on milk temperature, dry matter intake, and milk yield of lactating dairy cows. J. Dairy Sci. 86:232-242. 